Levitsky A. P., Mudrik L. M., Khromagina L. N., Sevostianova T. A., Selivanskaia I. A. Lipopolysaccharide increases lysozyme adhesion to chitin. Journal of Education, Health and Sport. 2019;9(11):240-247. eISSN 2391-8306. DOI http://dx.doi.org/10.5281/zenodo.3558921

https://apcz.umk.pl/czasopisma/index.php/JEHS/article/view/JEHS.2019.09.11.021

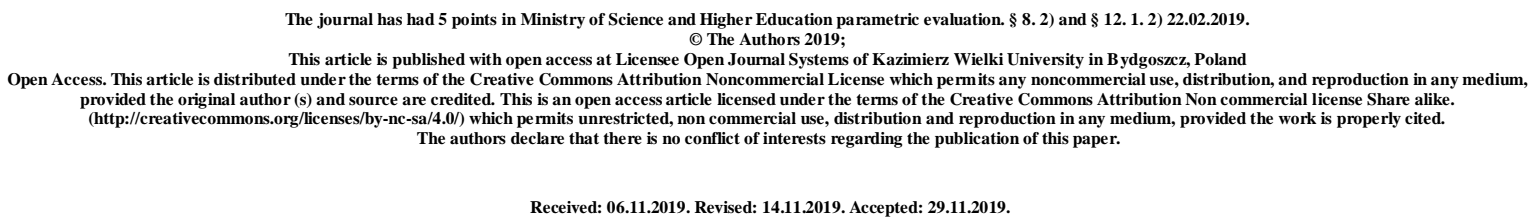

UDC 616.153:577.152:616.633:612.31

\title{
LIPOPOLYSACCHARIDE INCREASES LYSOZYME ADHESION TO CHITIN
}

\author{
A. P. Levitsky, L. M. Mudrik, L. N. Khromagina, T. A. Sevostianova,
}

I. A. Selivanskaia

\section{State Etablishment «The Institute of Stomatology and Maxillo-Facial Surgery of the National Academy of Medical Science of Ukraine» flavan.ua@gmail.com}

\footnotetext{
Abstract

Background. To study the effect of lipopolysaccharide on the adsorption of lysozyme on chitin.

Methods. Egg white lysozyme, lipopolysaccharide and chitin were used. The lyophilized cells of M. lyzodeikticus were used as a lysozyme substrate. Lysozyme activity was determined by the bacteriolytic method using different concentrations $(8-512 \mu \mathrm{g} / \mathrm{ml})$. Lysozyme adsorption on chitin was determined by the loss of lysozyme from solution after shaking with chitin. The effect of lipopolysaccharide $(0.6-40 \mu \mathrm{g} / \mathrm{ml})$ on lysozyme adsorption was evaluated by the loss of lysozyme from the solution after shaking with $50 \mathrm{mg}$ of chitin.

Results. In determining the activity of lysozyme by the bacteriolytic method, the linear nature of the dependence of activity on the concentration of the enzyme is observed only at low concentrations (8-100 $\mu \mathrm{g} / \mathrm{ml}$ ). Lipopolysaccharide does not affect the bacteriolytic
} 
activity of lysozyme, however, dose-dependently increases the adsorption of lysozyme on chitin.

Conclusion. Lipopolysaccharide increases the adsorption of lysozyme on chitin.

Keywords: lysozyme, lipopolysaccharide; chitin; bacteriolysis; adsorption of lysozyme on chitin.

\section{INTRODUCTION}

Lysozyme, a hydrolytic enzyme (EC 3.2.1.17), which cleaves the $\beta$ - $(1,4)$-gluctoside bond between $\mathrm{N}$-acetylglucosamine and $\mathrm{N}$-acetylmuramic acid in the cell wall glycopeptides of microorganisms [1-3].

Lysozyme is one of the important factors of nonspecific immunity in the human body and many animals in connection with its ability to lyse a number of bacteria [4]. Lysozyme most easily hydrolyzes streptococcal cells, one of which (Micrococcus lysodeikticus) is even used as a substrate to determine lysozyme activity [2].

However, in addition to bacteriolytic activity, lysozyme affects many biochemical and physiological processes in the body. So, it increases the chemotaxis of leukocytes [1], stimulates the lymphocytic system of specific immunity [5], and has hepatoprotective and mucosoprotective effects $[6,7]$.

More recently, a group of Moscow biochemists [8] found that lysozyme binds to the intestinal endotoxin lipopolysaccharide, which is secreted by gram-negative bacteria and has a very strong pro-inflammatory effect [9]. On this basis, they proposed the use of immobilized lysozyme for sorbtion of lipopolysaccharide from the blood of patients with sepsis [8].

We have previously shown that lipopolysaccharide (LPS) inhibits lysozyme activity in many body tissues in animal experiments in vivo, and is hundreds of times stronger than any other toxins [10]. At the same time, in experiments in vitro we were not able to establish a direct inhibitory effect of LPS on lysozyme [2].

All this determined the aim of this study, which is to study the possible effect of LPS on some other properties of lysozyme, for example, on its ability to adsorb on a substrate such as chitin, which is even used as a substrate for determining the lysozyme content in biological media $[11,12]$.

\section{MATERIAL AND RESEARCH METHODS}

In the work was used the lysozyme preparation "Mayozyme $9000 \mathrm{~L}$ ", obtained from egg white, manufactured by MAYASAN Gida Sanayi ve Ticaret Anonim Sirketi, Turkey. 
Lysozyme activity was determined by the Gorin bacteriolytic method in the modification [2]. As the substrate used the preparation of lyophilized cells Micrococcus lysodeikticus ATCC No. 4698, manufacturer "Sigma", USA.

As a source of lipopolysaccharide used the drug "Pyrogenal", manufactured "Medgamal" N.F. Gamaleya Federal Research Center Epidemiology \& Microbiology. RF.

All lysozyme solutions (from $8 \mu \mathrm{g} / \mathrm{ml}$ to $512 \mu \mathrm{g} / \mathrm{ml}$ ) were prepared from the initial preparation with a protein concentration of $416 \mathrm{mg} / \mathrm{ml}$ by appropriate dilution in $0.1 \mathrm{M}$ phosphate buffer $\mathrm{pH}$ 6.2.

The corresponding dilutions of lipopolysaccharide were prepared on the same buffer, taking into account the concentration of the latter in the "Pyrogenal" preparation, equal to 100 $\mu \mathrm{g} / \mathrm{ml}$.

As a specific sorbent for lysozyme, the chitin preparation "Chitin from shrimp shells", manufactured by Sigma, USA, was used. It was preliminarily ground in a coffee grinder; the fraction was sieved through a $0.56 \mathrm{~mm}$ sieve and washed with a $\mathrm{pH} 6.2$ phosphate buffer.

The adsorption of lysozyme or a mixture of lysozyme with lipopolysaccharide was carried out by mixing $50 \mathrm{mg}$ of chitin with $2 \mathrm{ml}$ of solution for 15 minutes. After centrifugation at $2500 \mathrm{~g}$ for 10 minutes, the activity of non-adsorbed lysozyme was determined in the supernatant.

All determinations of lysozyme activity were carried out in 3-5 replicates and presented as average values.

\section{RESULTS AND DISCUSSION}

In table 1 and in fig. 1 presents the results of determining the bacteriolytic activity of lysozyme solutions with different protein contents. As can be seen from the data in table 1, the activity of lysozyme increases with increasing protein concentration, however, the specific activity is decreases. In fig. 1 shows that the dependence of the bacteriolytic activity of lysozyme on its content is linear only at very low concentrations of the enzyme (less than 100 $\mu \mathrm{g} / \mathrm{ml})$. This circumstance must be taken into account when determining the level of lysozyme in biological media.

As for the sharp (almost 10 times) decrease in the specific activity of lysozyme with an increase in its concentration, this circumstance can be explained by the ability of lysozyme molecules to form dimers, tetramers, even octamers when certain concentrations are reached $[13,14]$. 
Table 1

\begin{tabular}{|c|c|c|}
\hline $\begin{array}{c}\text { Protein concentration, } \\
\mu \mathrm{g} / \mathrm{ml}\end{array}$ & ml Activity, u/ml & $\begin{array}{c}\text { Specific activity, } \mathrm{u} / \mathrm{mg} \\
\text { protein }\end{array}$ \\
\hline 8,0 & 0,038 & 47,5 \\
\hline 16,0 & 0,045 & 28,1 \\
\hline 32,0 & 0,081 & 25,3 \\
\hline 64,0 & 0,146 & 22,8 \\
\hline 128,0 & 0,208 & 16,3 \\
\hline 256,0 & 0,241 & 9,4 \\
\hline 512,0 & 0,249 & 4,9 \\
\hline
\end{tabular}

Bacteriolytic activity of lysozyme depending on protein content

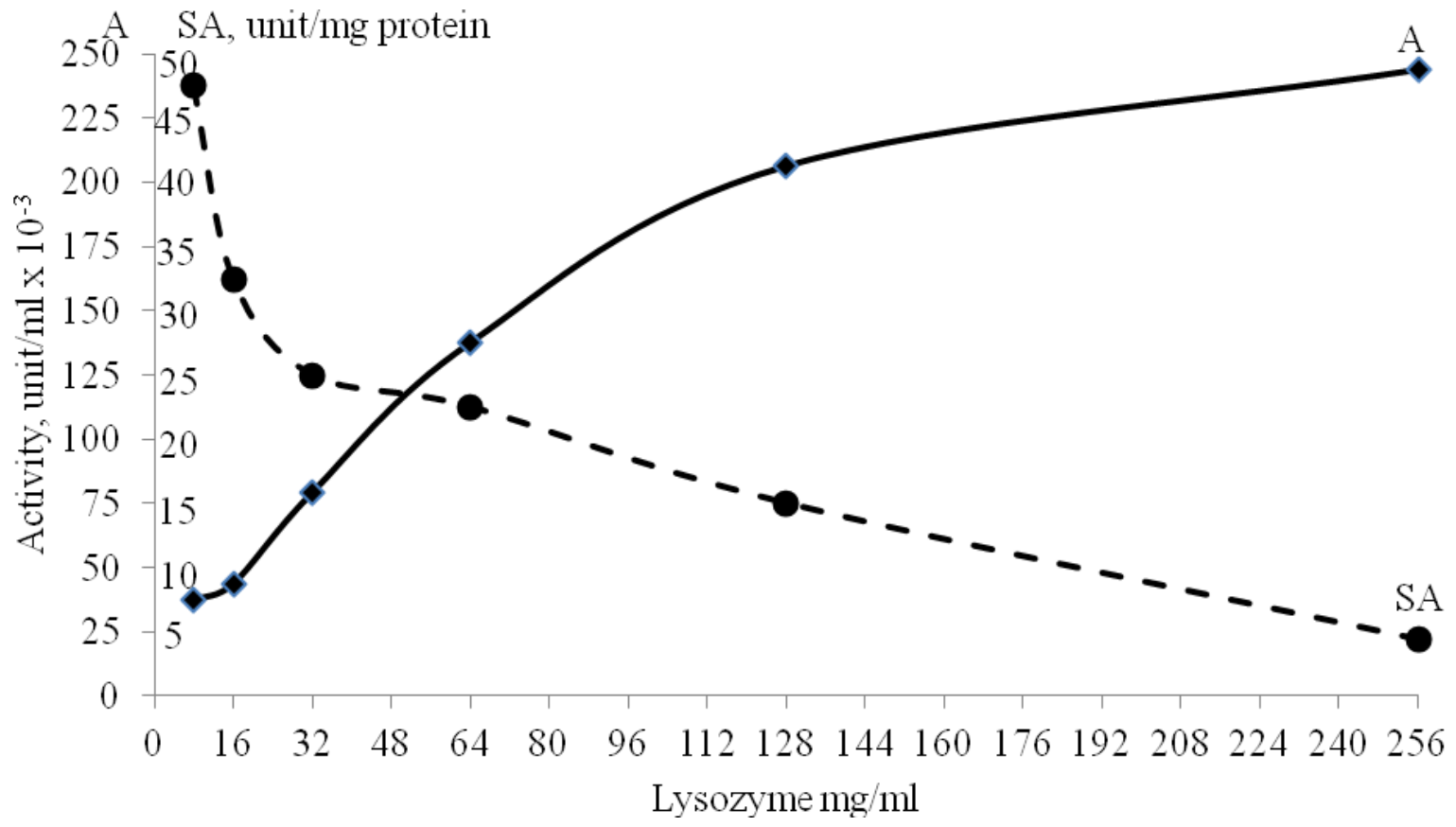

Fig. 1. The dependence of lysozyme activity on concentration

Table 2 presents the results of determining the effect of lipopolysaccharide on lysozyme activity. A mixture of lysozyme and LPS solutions was kept at room temperature for 15 minutes and then lysozyme activity was determined. As can be seen from the data of two experiments with different concentrations of lysozyme, lipopolysaccharide does not 
affect the bacteriolytic activity of lysozyme. This circumstance remains incomprehensible in light of the data on the ability of lipopolysaccharide to effectively reduce lysozyme activity in animal tissues in vivo [10].

Table 2

The effect of LPS on lysozyme activity

\begin{tabular}{|l|c|c|c|}
\hline \multicolumn{1}{|c|}{ Indicators } & $\begin{array}{c}\text { Lysozyme, units / } \\
\mathrm{ml}\end{array}$ & LPS, $\mu \mathrm{g} / \mathrm{ml}$ & Lysozyme + LPS \\
\hline Experience 1 & 404 & 40 & 404 and 40 \\
\hline $\begin{array}{l}\text { The content of components, } \\
\text { mcg / ml }\end{array}$ & $0,217 \pm 0,012$ & 0 & $\begin{array}{c}0,220 \pm 0,015 \\
\mathrm{p}>0,8\end{array}$ \\
\hline Lysozyme activity, units / ml & 202 & 40 & 202 and 40 \\
\hline Experience 2 & $0,128 \pm 0,008$ & 0 & $\begin{array}{c}0,126 \pm 0,009 \\
\mathrm{p}>0,7\end{array}$ \\
\hline $\begin{array}{l}\text { The content of components, } \\
\text { mcg / ml }\end{array}$ & & & \\
\hline Lysozyme activity, units / ml & & & \\
\hline
\end{tabular}

In addition to bacteriolytic activity, lysozyme has one more specific feature - it is selectively adsorbed on chitin [13, 14]. We decided to check how LPS affects the adsorption of lysozyme on chitin. The results of this check are presented in table 3 and in fig. 2 .

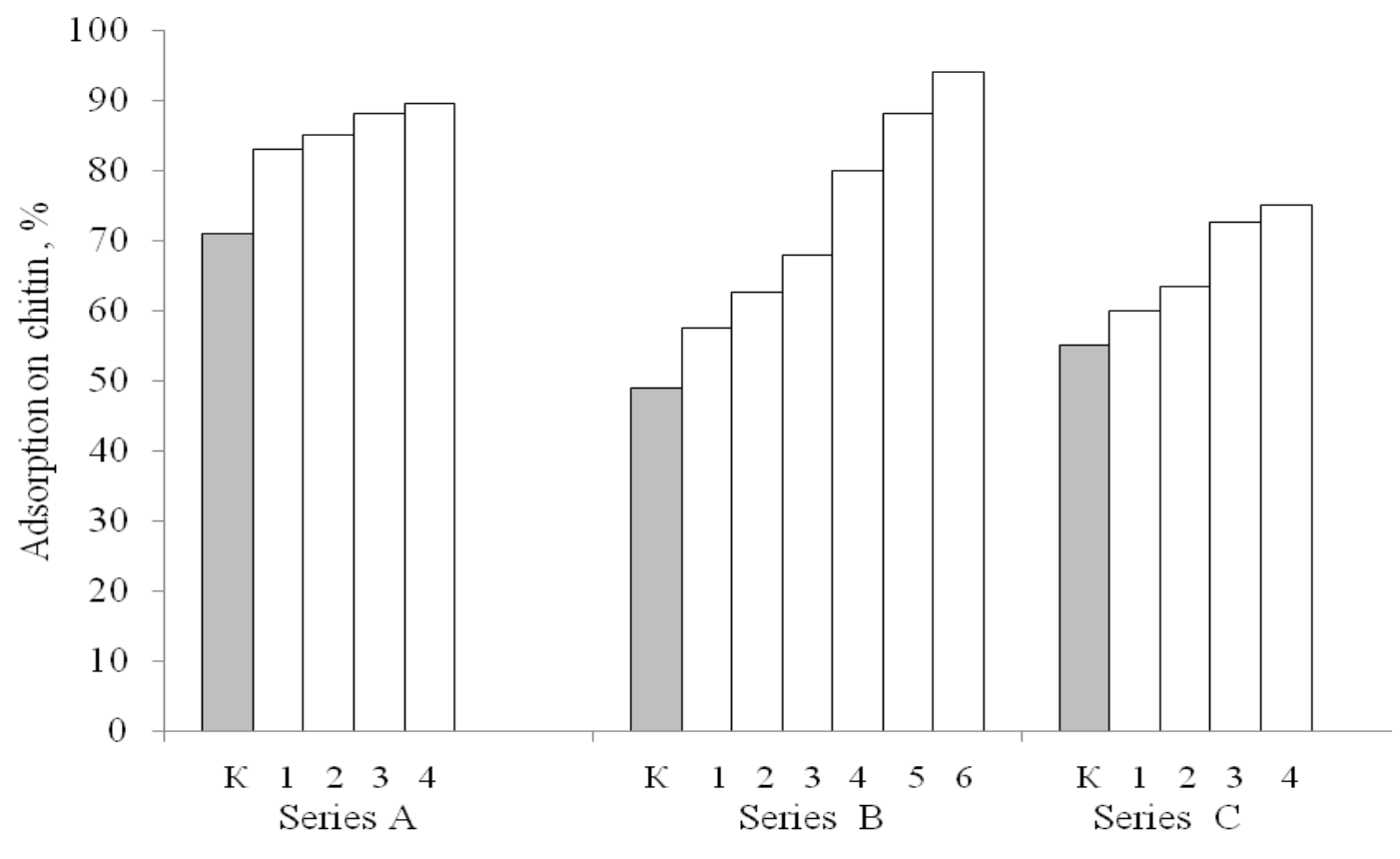

Fig. 2. The effect of LPS on the adsorption of lysozyme on chitin: Series A, $35 \mu \mathrm{g} / \mathrm{ml}$ lysozyme: 1 - LPS - $0.6 \mu \mathrm{g} / \mathrm{ml}, 2-1.25 \mu \mathrm{g} / \mathrm{ml}, 3-8.5 \mu \mathrm{g} / \mathrm{ml}, 4-10 \mu \mathrm{g} / \mathrm{ml}$.

Series B, $52 \mu \mathrm{g} / \mathrm{ml}$ lysozyme: 5 - LPS - $20 \mu \mathrm{g} / \mathrm{ml}, 6$ - $40 \mu \mathrm{g} / \mathrm{ml}$.

Series C, $104 \mu \mathrm{g} / \mathrm{ml}$ lysozyme 
The effect of LPS on the adsorption of lysozyme on chitin (50 mg)

\begin{tabular}{|c|c|c|c|}
\hline \multirow{3}{*}{ Series } & $\begin{array}{c}\text { Lysozyme, mcg / } \\
\text { ml. Activity, units / } \\
\text { ml }\end{array}$ & LPS, mcg / ml & $\begin{array}{c}\text { Activity after } \\
\text { adsorption on } \\
\text { chitin }\end{array}$ \\
\hline A & 35,0 & 0 & 0,034 \\
& Activity 0,115 & 0,6 & 0,030 \\
& & 1,25 & 0,029 \\
& & 2,5 & 0,022 \\
& & 5,0 & 0,020 \\
& & 10,0 & 0,024 \\
\hline & Activity 0,192 & 0 & 0,131 \\
& & 0,6 & 0,089 \\
& & 1,25 & 0,088 \\
& & 2,5 & 0,070 \\
& & 5,0 & 0,037 \\
& & 10,0 & 0,032 \\
\hline D & Activity 0,123 & 0 & 0,041 \\
& & 10,0 & 0,022 \\
& & 20,0 & 0,015 \\
& & 40,0 & 0,007 \\
\hline & Activity 0,263 & 0 & 0,117 \\
& & 0,6 & 0,115 \\
& & 1,25 & 0,095 \\
& & 2,5 & 0,081 \\
& & 5,0 & 0,070 \\
& & 10,0 & 0,072 \\
\hline
\end{tabular}

The effect of different LPS concentrations (from 0.6 to $40 \mu \mathrm{g} / \mathrm{ml}$ ) was studied in 3 lysozyme solutions containing $35 \mu \mathrm{g} / \mathrm{ml}, 52 \mu \mathrm{g} / \mathrm{ml}$ and $104 \mu \mathrm{g} / \mathrm{ml}$ of the enzyme. The results presented in table 3 indicate that the addition of LPS dose-dependently enhances the adsorption of lysozyme on chitin, and the activating effect of LPS is already apparent from very low concentrations - $0.6 \mu \mathrm{g} / \mathrm{ml}$. The most sensitive to the action of LPS was the concentration of lysozyme, equal to $52 \mu \mathrm{g} / \mathrm{ml}$. Based on these data, the degrees of lysozyme adsorption on chitin were calculated, shown in Fig. 2. As can be seen from the figure, the most clear dose dependence of the activating effect on the adsorption of lysozyme LPS is at a concentration of lysozyme $52 \mu \mathrm{g} / \mathrm{ml}$ (series of experiments B and C).

To explain the activating effect of LPS on the adsorption of lysozyme, we assume that LPS promotes depolymerization of lysozyme aggregates, converting di-, tetra- and octomeres to the monomeric state, which more easily interacts with chitin.

However, the biological role of the activating effect of LPS on the adsorption of lysozyme still needs to be clarified. 


\section{CONCLUSIONS}

1. Dose-dependent bacteriolytic activity of lysozyme appears only at very low concentrations (less than $100 \mu \mathrm{g} / \mathrm{ml}$ ).

2. LPS does not inhibit the bacteriolytic activity of lysozyme in vitro.

3. LPS dose-dependently enhances the adsorption of lysozyme on chitin, starting from a concentration of $0.6 \mu \mathrm{g} / \mathrm{ml}$.

\section{REFERENCES}

1. Barabash AD, Levitsky AP. Enzymatic mechanisms of antimicrobe defence of at oral cavity. Questions of medical chemistry. 1978; 24(3): 291-310. (in Russian)

2. Levitsky AP. Lysozyme instead of antibiotics. Odessa, KP OGT, 2005: 74. (in Russian)

3. Sariri R, Gafuri Kh. Proteins of tears: normal, with eye disease and when wearing contact lenses. Biochemistry. 2008; 73(4): 469-482. (in Russian)

4. Bukharin OV, Usvetsov BYa, Matiiash IN [and others]. The reference of lysozyme antimicrobe activity. Antibiotics. 1976; 9: 805-808. (in Russian)

5. Dobrotina NA, Kazatskaia ZhA, Emelianova TIu. Lysozyme as immunological modulator. Questions of medical chemistry. 1988; 33: 66-69. (in Russian)

6. Maianskii DN, Kutina SN, Shcherbakova EG. Influence of lysozyme on hepatocytes resistence. Antibiotics and chemotherapy. 1988; 33(2): 128-131. (in Russian)

7. Kutina SN, Zubakhin AA. Liver resistance to damage of $\mathrm{CCI}_{4}$ at stimulation of macrophages with the preparations of different categories. BEBIM. 2000; 129(6): 620-622. (in Russian)

8. Levashov PA, Matolygina DA, Ovchinnikova ED [and others]. New sorbent based on covalently immobilized lysozyme to remove bacterial lipopolysaccharide (endotoxin) from biological fluids. Biochemistry. 2019; 84(1): 100-108. (in Russian)

9. Yakovlev MYu. The elements of endotoxin theory of human physiology and pathology. Physiology of man. 2003; 29(4): 98-109. (in Russian)

10. Levitsky AP, Ostafiichuk MA, Uspenskii OE [and others]. The influence of different pathogens on the lysozyme activity into tissues of rat oral cavity. Journal of Education, Health and Sport. 2017; 7(8): 1070-1081.

11. Cherkasov IA, Kravchenko NA. An improved method for the isolation of lysozymes by enzyme-substrate chromatography. Biochemistry. 1969; 34(5): 1089-1091. (in Russian) 
12. Cherkasov IA, Kravchenko NA. Copyright certificate 178771 USSR, IPC C12K. A method for producing enzyme preparations of lysozymes from their raw materials. Application number 943666/28-13. Date of filling: 17.11.1965. Publ.: 19.11.1966. Bul. № 4. (in Russian)

13. Lakhtin V, Kostanova E, Arbatskii N. Purification and characterization of multiple forms of papaya latex lysozyme. Applied biochemistry and microbiology. 1995; 2: 247-254. (in Russian)

14. Islam R, Kite J, Baker AS [and others]. Affinity purification of hen egg lysozyme using sephadex G75. African J. of Biotechnology. 2006; 5(20): 1902-1908. 